\title{
Legislative Policy in Support of Vietnam SMEs: Analysis and Propositions
}

\author{
Quy Nguyen Hoang ${ }^{1}$ \\ ${ }^{1}$ National Academy of Public Administration, Hanoi, Vietnam \\ Correspondence: Quy Nguyen Hoang, National Academy of Public Administration, 77 Nguyễn Chí Thanh, Đống \\ Đa district, Hanoi, Vietnam. Tel: 84-90-346-3669. E-mail: nghoangquy@ yahoo.com
}

Received: November 20, 2015

Accepted: December 29, 2015 Online Published: January 25, 2016

doi:10.5539/ijef.v8n2p226

URL: http://dx.doi.org/10.5539/ijef.v8n2p226

\begin{abstract}
This paper focuses on legislative policy in support of Vietnam SMEs. On the basis of literature review, we will analyze the current policies of Vietnam Government and also experiences of some relevant countries. Then, we will propose recommendations for policy in support of SMEs in their development and competitiveness improvements, such as in finance, law, investment in technology, manpower development or trade promotion activities... face to near future international economic integration, particularly the Trans-Pacific Partnership (TPP) recently reached.
\end{abstract}

Keywords: SME, government, policy, support, proposition, Vietnam

\section{Introduction}

The context of globalization and international economic integration offer to Vietnamese enterprises many opportunities; it involves also challenges for Vietnam when small and medium sized enterprises (SMEs) account for $97.5 \%$ (VNASME, 2014 (Note 1)). In order to improve SMEs' integration capacity, in recent years, Vietnam government has proposed several solutions to support them in finance, credit, technology, human resources; information and consulting services; market promotion and expansion... that were specified in the Decree No.56/2009/NĐ-CP promulgated on 07/9/2012 and the 5-Year Plan for Vietnam SMEs development in the period of 2011-2015. However, the positive impacts of these policies were not significant as expected of Vietnam government in SMEs' development and contributions to economy (Tô Hoài Nam, 2015). According to the recent survey of VCCI (Vietnam Chamber of Commerce and Industry) in 2014, Vietnam SMEs become smaller and less effective; the number of micro enterprises gradually increases in Vietnam.

In this context, this paper focuses on legislative policy in support of Vietnam SMEs. On the basis of literature review, we will analyze the current policies of Vietnam Government and also experiences of some relevant countries. Then, we will propose recommendations for policy in support of SMEs in their development and competitiveness improvements face to near future international economic integration, particularly the Trans-Pacific Partnership (TPP) recently reached.

\section{Theoretical Framework}

\subsection{Introducing to SMEs}

In theory and in practice, the basic criterion for classifying small and medium sized enterprises is to base on the strength of the labour force capital. With criteria as such, small and medium-sized enterprises can be classified into micro-sized enterprises, small-sized enterprises, micro-sized enterprises. According to the World Bank, small and medium-sized enterprises are enterprises having a strength of from 10-300 people. According to the countries of the Organization for Economic Cooperation and Development (OECD, 2010), SMEs are financially independent companies but not affiliated companies of big companies. SMEs have a strength of workforce from 10-250 in the European Commission (2007) and 10-200 in the USA. Pecuniary assets are also used to define SMEs. In the EU, SMEs must have annual revenue equal to or over Euro 40 million and/or the balance sheet value must not exceed Euro 27 million.

In Vietnam, under the latest legal document in 2013 (the Circular No. 16/2013/TT-BTC promulgated on 08/12/2013), small and medium-sized enterprises including branches, subsidiaries but financially independent units, cooperatives (employing under 200 employees working full time and with annual revenue not exceeding 
VND 20 billion will be considered SMEs. Statistical data from Vietnam Association of Small and Medium Enterprises indicated that till the end of 2014, throughout the country, there were over 500 thousand small and medium-sized enterprises, accounting for $97.5 \%$ of the total number of enterprises in operation. Every year, SMEs contribute about $40 \%$ of GDP and attract $51 \%$ of the labour force of the whole country. Investment capital of such enterprises amounts to USD 121 billion and accounts to $30 \%$ of the total registered capital of enterprises. This shows that SMEs play an important role in the national economy, that support in developing this enterprise model is the correct line of Vietnam Government in the roadmap for national economic development.

Besides the features and role of general enterprises, SMEs have their own characteristics (Shapero, 1982). Firstly, SMEs are often restricted in both capital and labour, budget for management and training not high. Lines of business of these enterprises are often in the areas directly for life, products with high purchasing power, making use of local capital and human resources. Secondly, competitive capacity of SMEs in the market is still low, sensitive to market fluctuations and economic crises. Therefore, the profits gained for enterprises are not high. Nevertheless, this is also the form of enterprise at low fixed cost, with quick capital restoration, and ease of change in facilities and equipment...Thirdly, the strength of workforce in SMEs is usually at an average level (from 10-300 people), much restricted in professional skills. This is resulting from the fact that out of little capital, enterprises do not have many conditions for human resource investment, training and development.

In many countries over the world, particularly in developing countries, SMEs normally account for $90 \%$ of the number of enterprises and contribute considerably to GDP of such countries. The role of SMEs is undeniable and is assessed in the following aspects: First, SMEs help create jobs for employees, increase income, solve the problem of local manpower for local people. In addition, as this form of enterprise does not entail highly qualified workers, the people access is thus very great. This is an advantage but also a weakness of the model of SMEs, which reduces enterprise competitive capacity in business activities.

Second, creating sound competitive environment Due to the feature hat SMEs account for most of the total number of enterprises, these require high competitive capacity not only among SMEs but also between these enterprises and enterprises on a larger scale. This helps increase flexibility of enterprises, forcing them to find way to exploit every opportunity to develop, make full use of the local human resources and material resources. That if each enterprise is proactive and strengthen is competitiveness will contribute to building a dynamic and effective economy.

Third, SMEs serve as satellites for large-sized enterprises and also premise for the development of large-sized enterprises. SMEs can complement large-sized enterprises as providers of inbound materials, intermediate outlets for selling outbound products or processing products in several steps of large-sized enterprises.

In Vietnam, SMEs play an important role in the national economy for their strength in large numbers and great contributions to the country and social development. The number of SMEs has increased remarkably in recent years. In the period of 2011-2013, 224,000 enterprises were set up throughout the country. Data from Vietnam Association of Small and Medium Enterprises has shown that by the end of 2014, throughout the country, there were about 500,000 SMEs (accounting for 97.5\% of the total enterprises in operation and in 2015, it is expected that there shall be 700,000 enterprises. Contributions from SMEs to the national economy in 2014 accounted for $40 \%$ of the nationwide GDP and attracted $51 \%$ of domestic workforce. These figures have one more time confirmed the undeniable role of SMEs towards the economy of any country in general and the economy of Vietnam in particular.

\subsection{Theoretical Framework on Policies in Support of SMEs}

In the literature, there are several researches analyzing the role of State policies in support of SMEs. Hölzl and Friesenbichler (2008) indicate that the growth of a country in general or of an enterprise relies much on the State's development strategies. When countries have different development policies will create different comparative advantages among enterprises of such countries. These policies include policies for regulating macro-economy, policies on law or policies for strengthening the binding of enterprises to the State. To illustrate this, he used the EU economy as background and confirmed that the EU had proper economic policies to create a powerful economic community like it today. The EU Economic Community has always provided timely support for SMEs of the member countries, creating the internal links among the countries in the bloc through the use of the common Euro currency and the European Central Bank.

Cunningham (2008) introduced the theory of policies in support of enterprises. In his research, he described the general context of the development levels of some European countries respective to the policies of the governments of such countries. The European Community is a powerful link block, apart from the general economic policies under the signed agreements, each member of the Community has its own policies in support 
of SMEs in its country. Different business environments stimulate different economic development levels among the countries in the European Community.

Enterprise Research Centre in England (ERC) also confirmed that State's development policies play an important role in supporting SMEs (Roper \& Hart, 2013). This important role is displayed in the fact that policies not only create potentialities for enterprises to develop but also act as support for enterprises to overcome crisis. The State's policies involve support in providing information for SMEs about trademark, development tendency of the region and the world, strengthening the linking network between medium and small sized enterprises, between enterprises with the State and R\&D centers. In addition, enterprises also need supports from the State in trade promotion, market research expansion. Particularly, financial policies play an extremely important role in the sustainable development of enterprise in general and of SMEs in particular.

From the researches by economic scholars in the world, particularly the ones as mentioned above, the State's policies in support of SMEs involve: (1) finance, credit; (2) legal corridor; (3) investment and development of technology, engineering and human resources; (4) information and consultation; (5) market promotion and expansion. This, however, is only a general model, whereas the application of such policies in every country differs and depends on each country's economic characteristics. While effectuating solutions to support SMEs, there should be a harmony between the policies so as to produce the highest economic effects. Especially, the linking between the State and SMEs as well as research centers, economic experts should be strengthened for planning and providing suitable support policies and with timely correction when necessary. By doing this well, the competitive capacity of SMEs in each country will considerably improved.

The theories of SMEs and the State's policies in support of this form of enterprise by several scholars in the world, as such, will be premise for the literature study deeply the actual situation of support for SMEs in Vietnam. On that basis, the literature is intended to orient some policies as which shall serve as references for the State to have the most correct and proper lines in enterprise development.

\section{Methodology}

To achieve the research results, two main methods were employed in the subject. The first one was method of primary research based on collecting SME-related materials such as theories of SMEs, theories of policies in support of SMEs, the actual situation of support for SMEs in Vietnam as well as the support policies effectuated by the State... The materials collected were the studies of several economic scholars in the world, domestic and foreign economic magazines, reports, statistical data about Vietnam's SMEs from the Ministry of Planning and Investment, VINASME - Association of Small and Medium Enterprises...

The data collected shall serve as grounds for the second method. This method is effectuated by interviewing some owners of SMEs, several economic experts and leaders working in policy planning a activities...The questions were about issues appertaining to the advantages and disadvantages of small and medium-sized enterprises, the supports provided for them from the State as well as orientation of policies in support of SMEs in the coming years...

The process of collecting data from reliable sources and interviewing was followed by the process of processing the data. Data was classified into: Data on theoretical bases, statistical data, actual situation data through interviews. From that the author studied and built the framework for the subject, integrated the data so as to have a complete research work.

\section{Research results}

\subsection{Analyzing Current Governmental Policies in Support of SMEs in Vietnam}

In recent years, Vietnam government has promulgated numerous correct, timely policies in order to create legal corridors for the establishment, operation and development of enterprises in general and of SMEs in particular. Such policies was specified in the Decree No.56/2009/NĐ-CP on support for small and medium-sized enterprise development promulgated on 30/6/2009. Along with that was the Enterprise Law amended in 2015. The State set up 5-year plan for SMEs development in the period of 2011-2015 (promulgated attached to the Decision No. 1231/QĐ-TTg dated 07/9/2012) which specified numerous solutions to support SMEs as set out in the Decree No.56/2009/NĐ-CP. The Government's support policies for SMEs concentrated on the following contents:

Finance, credit supports: The State supported SMEs in borrowing loans at commercial banks, extending debt repayment time of enterprises. Thereupon, as from May 2012, the State Bank of Vietnam has stipulated to apply minimum short-term loan interest in VND in some preferential areas including SMEs at a rate lower 1-2\%/year than in other lines of business. This helps solve the capital problem-the biggest problem to SMEs. Besides, enterprises can be supported by extending and reducing some kinds tax such as personal income tax, land rent 
charge...

Legislations: In order to reduce enterprise weaknesses in getting access to information and law enforcement, to minimize business risks, the State has implemented many a legal support policy for enterprise in general and for SMEs in particular. The amended Enterprise Law 2015 shall serve as the most important legal ground for SMEs to carry out their business activities under provisions of the law. This law institutionalizes the right to freedom of enterprises, including the right to freedom of setting up enterprises, freedom of managing, freedom selecting scale, location and business lines, except the business lines banned by the law. Besides, in order to create a clear legal environment for enterprises to operate, our State always strive to carry out the process of administrative reform, particularly administrative procedures, with the most prominent point is to simplify procedures for activities of setting up enterprises, registering for business, reforming administrative procedures in the areas of taxation and customs...

Technology investment and human resources development supports: In order to support technological, engineering development of SMEs, the Ministry of Science and Technology coordinates actively with ministries, branches, localities in carrying out activities to support enterprises in innovating, improving technology capacity through the Program to Assist Businesses in Developing Intellectual Property in the period of 2011-2015 and National Technological Innovation Program till 2020. According to the report of Enterprise Development Department at the Council for Encouragement and Development of Small and Medium-Sized Enterprises in December 2014, the Ministry of Science and Technology coordinated with the Monitoring Committee of the National Technological Innovation Program till 2020 in surveying, selecting 120 units, enterprises achieving high production and business performance based on utilizing quality human resources and application of technology innovation; coordinated with the Office of Innovation Partnership Programme (IPP) in carrying out 04 projects for support in completing new product manufacturing and applying technology innovation. With respect to human resource development, in 2014, the Ministry of Planning and Investment and the Ministry of Finance promulgated the joint Circular No. 04/2014/TTLT-BKHĐT-BT dated 13/8/2014 guiding through training, refresher training human resources for medium and small sized enterprises. Accordingly, the State would concentrate on improving management capacity for small and medium-sized enterprises in several areas, sectors in which priority is given to training under the development orientation of the State; diversify forms of training (training on the television, on the Internet) so as to strengthen the capacity to get access to training for small and medium-sized enterprises; supplement intensive training courses of small and medium-sized enterprises for some intensive special subjects. In 2014, ministries, organizations, associations was expected to hold and carry out 730 business start-up and business administration training courses (with a total budget of VND 35 billion) for over 25,000 trainees being entrepreneurs, managers of SMEs nationwide (Report by the Enterprise Development Department at the meeting of the Council for Encouragement and Development of small and medium sized enterprises in December, 2014).

Information and consulting services: In order to establish multidirectional information relationships between State bodies at central and local levels, between the State and enterprises, the Government has assigned the Ministry of Planning and Investment (Enterprise Development Department) to make project to provide information for SMEs through website www.business.gov.vn. This is where enterprises will update, share information, promote products, services, link business, initiate opportunities to cooperate between enterprises. In addition, in localities, contacts between enterprises and provincial leaders in order to clear enquiries, difficulties and provide information for SMEs. Activities as such produce practical effects, helping enterprises get deeper access to the sources of information to serve their manufacture and business activities.

Market promotion and expansion supports: In 2013, the National Trade Promotion Program with the total budget for implementation of VND 93,730 million attracted over 6,000 turns of small and medium-sized enterprises to join (Report by the Enterprise Development Department at the meeting of the Council for Encouragement and Development of small and medium sized enterprises in December, 2014). The Program made favourable conditions for SMEs to bring Vietnam's exports the traditional markets such as the USA, EU, China, Japan and expand to some other markets. In addition, the Ministry of Industry and Trade was also active in carrying out the national branding program in order to support enterprises in developing the brand names of the commodities with competitive advantages of Vietnam such as rice, coffee, catfish, handicraft art articles... At the local level, most provinces supported market expansion through activities of holding trade fairs, exhibitions, trade promotion delegations in the region and abroad under national trade promotion program objectives. Many provinces carried out such activities vigorously such as Danang, Ca Mau, Binh Duong, Dong Nai, Lam Dong, Dak Lak et al.

It can be said that the mechanism of policies in support of SMEs promulgated by the State of Vietnam has been relatively complete and comprehensive in all areas. Nevertheless, in the roadmap for effectuating these policies 
there still exist so many big problems. The access to sources of support is still very difficult. The result of interviewing 105 owners of SMEs in Vietnam about the possibility to access the support policies of the State, $40.5 \%$ of them answered they had access, $29 \%$ met with difficulties and $30.5 \%$ didn't have access. The causes as provided were mainly the redundancy in procedures for the policies in support of enterprises and the lack of close coordination between agencies, departments, sectors.

Further, as most State policies have been targeted at enterprises in general, it's more difficult for SMEs to get access to. Particularly, some SMEs, when interviewed, answered that they didn't know about that the State had some policies in support of enterprises due to poor legal propaganda, dissemination activities. Therefore, SMEs in Vietnam still encounter many difficulties in the solving the capital technology, labour... problems. And results in the fact that enterprises very likely to be dissolved or wound up when confronted with economic crises inside the country and in the region.

\subsection{Experiences of Some Relevant Countries}

We analyze also policies in supports of SMEs in some relevant countries for recommending for Vietnam Government.

Hong Kong: in order to help SMEs boost production and improve competitive capacity, the Government of this country attached special importance to the development of solutions in support of science and technology (Autio et al., 2007). Proceeding in this orientation, the Government of Hong Kong set up Applied Science and Technology Research Institute (ASTRI) for science and technology transfer and application to enterprises in general and to SMEs of Hong Kong in particular. Apart from technology supports, ASTRI is also a place for training and developing human resources in Hong Kong and attracting external human resources to come and work in this island state. Along with ASTRI, Hong Kong Science Park (HKSTP) was set up and is the unit fairly successful at supporting SMEs in applying technological advances to production and business activities to improve competitive capacity of Hong Kong enterprises.

Malaysia: The Government promulgated the Law on Investment Encouragement in 1986 and Law on Corporate Tax in 1967 aimed at supporting enterprises in general and SMEs in particular in solving problems and creating momentum for development. These laws stipulate preferential policies in each specific sector such as agriculture, forestry, and service (Autio et al., 2007).

For industry, the State effectuated re-granting capital credit to SMEs at preferential interest rates Malaysia Central Bank and Negara Bank, from that to solve the problem of capital for SMEs inside the country, particularly enterprises involved in export. Along with this are policies to encourage SMEs to expand the market by exporting to non-traditional markets. These enterprises are entitled to charge twice as much credit insurance premium. These enterprises are entitled to charge twice as much credit insurance premium and this has been approved by Minister of Finance.

For agriculture, in order to support SMEs's activities in agriculture, the State permits full exemption from import tax on raw materials in the case such raw materials are not domestically produced. As to enterprises with export activities, support in export equals $5 \%$ of export turnover so as to encourage enterprises to export some certain agricultural products.

South Korea is a developed economy in Asia with respectable advancements made in economy and in science and technology. To have such achievements is partly due to the correct strategies of the South Korean Government. South Korea's economic development policies incorporate different stages, in which, the 3rd stage started from the post-1980 and concentrated support for economic development of SMEs. The focus of these support policies was on the areas of credit, investment in technology... (Lilischkis, 2011).

As to policies on credit and technology, the State encourages financial institutions to permit SMEs to borrow loans when these enterprises have projects with good prospects but do not have sufficient mortgage assets nor credit documentation to prove their solvency. In order to support enterprises in borrowing loans, the Korea Technology Credit Guarantee Fund (KOTEC) was set up in 1989. KOTEC's duties involve guaranteeing to support enterprises in borrowing loans, speeding up SMEs development. KOTEC 's activities are being carried out in all localities. KOTEC 's branches shall examine dossiers and appraise reliance of the borrowing enterprises, their solvency and purposes of the loans, particularly nature of the technological innovations which loans will bring about. The appraised conclusions will be submitted to banks for lending decision. Thanks to KOTEC 's supports, small and medium-sized enterprises in South Korea can easily get access to bank loan resources when there is an agency comes forwards with guaranty and evidence to prove their financial capacity. This is a very valuable experience which the Government of Vietnam should take into consideration and learn. 
Especially, the Government of South Korea attaches special importance to supporting research programs in the regions all over the country. Regional research centers have been set up and the State guarantees, supports in capital and $80 \%$ of salary for experts. This serves as foundation for the State to have a close look at the actual situation of enterprises so as to supply proper policies.

Singapore: As a small country in geographical terms in Asia, yet Singapore's economy is not "small" at all. In 2010, Singapore ranked third for global competitive capacity and regarded an economy with prospects in the region with $99 \%$ of enterprises as SMEs. Hence, for the economic development purpose, the State of Singapore gives considerable priorities to SMEs (Lilischkis, 2011).

To support SMEs, the Government pays special attention to capital for production. Those enterprises with high potential and creativeness will be considered by the Government for support in finance. Good students after graduation will be selected for support in setting up enterprises and many of them have become excellent entrepreneurs. The State supports in capital through guaranty with the banks to permit SMEs to borrow and be exempted from tax when the enterprises are in difficulties due to natural calamities or force majeure. The State also pays special attention to human resource training for SMEs, particularly the enterprises involved in the export market. As to these enterprises, the Government sets up training funds in order to improve competences of directors, managers and further improve their deep and wide knowledge for integration. Providing SMEs with information is also an effective support channel of the State of Singapore. Internal Enterprise Singapore (IE) directly under Singapore Ministry of Industry and Trade has a network of over 30 offices in many countries over the world. The duties of these offices are to collect and provide market information; Coordinate in arranging domestic enterprise groups to go abroad for surveying, looking for partners; Support in holding conferences, workshops abroad; Strengthen co-operation, relations with other countries to help them understand more about Singapore... Through these offices, domestic enterprises can obtain necessary information about the business environments in countries before deciding to invest in. In Vietnam at present, I.E. has two representative offices in Hanoi and Ho Chi Minh City and these are operating in an fairly effective manner.

Japan: policies in support of SMEs in Japan are aimed at narrowing the gap between small and medium-sized enterprises and large-sized enterprises (Lilischkis, 2011). In 1999, the Government of Japan amended the Law in Support of SMEs, with emphasis placed on policies for enterprise renovation, for support in tax and finance. In late 2009, the Japanese cabinet adopted the New Growth Strategy which attaches special importance to SMEs. The goal of this strategy is to provide support in finance, technology, labour and to create clear legal environment for SMEs. In recent years, Japan has undergone numerous changes in policies on SMEs, from philosophy to finance, promotion and development, groups... The network of support for SMEs in Japan is divided into different levels, from Department of SMEs to make policies on SMEs nationwide to Precinct to make policies on SMEs in localities through METI Regional Committees at all levels. Under the correct policies and complete implementation, SMEs in Japan have confirmed their competitive capacity in the domestic and international markets and helped become one of the most robustly developed in the Asian region.

Hungary has also carried out numerous policies in support of enterprise development, particularly SMEs, proceeding from the awareness of the role and importance of this model of enterprise (Autio et al., 2007). The focus of Hungary's support policies is on tax reduction, restoration of the program to get access to loans for SMEs, attraction of foreign investment capital from countries of the EU, and strengthening capital use performance. This has helped solve the problem of capital for Hungary's SMEs. In particular, the State of Hungary always pays special attention to technological development, application and intellectual property rights in SMEs. That's why in this country, there are funds exclusively for technological company development. The Information Technology Venture Capital Fund (ITVCF) was set up in order to support technological enterprises in their start-up, capital development and mode of management. Along with that, the Office of Cabinet of Hungary made VIVACE (2004), this is a program specializing in providing and advising on solutions, patents, and intellectual property rights protection for SMEs. In addition, the State also carries out administrative reform, minimizes bureaucracy in State agencies and enterprises to create friendly business environment for co-development.

\section{Implications of the Results}

From the overview of the actual situation of policies in support of SMEs in Vietnam and the lessons of experience withdrawn from several countries in the world, the subject arrives at proposing some basic solutions with which the State can implement the policy marking process correctly and effectuate it in the most effective manner in support of SMEs. The State's support policies can be oriented according to some suggestions below:

Firstly, continuing to complete the legal framework, create transparent business environment for SMEs to 
operate: Based on the legal documents promulgated, the State should check and has timely corrections, closely to the actual situation of SMEs. Administrative procedures, though under reform, not yet on a radical manner, still redundant, complicated and causing many difficulties to enterprises. Administrative reform, application of science and technology to the implementation process to achieve the highest performance thus should be strengthened.

Secondly, strengthening financial and credit support for SMEs: There have been numerous policies on financial support, however, it is still difficult for enterprises to get access to this due to different causes. The State therefore should create the best conditions for SMEs to access the Government's preferential capital resources. If necessary, the Government should take into consideration and move towards setting SMEs development funds. These funds shall be used exclusively to provide finance support to SMEs with feasible projects, those enterprises that produce new products of high values... By doing well this task, Vietnam's SMEs will overcome difficulties in investment capital - the biggest restriction of SMEs at present.

Thirdly, orienting the operating model of focal point agencies in implementing policies in support of SMEs at Central and local levels: Reality has shown that our State's support policies have been relatively complete and comprehensive, nevertheless, when effectuated in practice, these were revealed to be incomplete and ineffective; hence the limited accessibility to the Government's supports of SMEs in our country. The State thus set up focal agencies to implement policies in support of SMEs as well as a system of assistance agencies from Central to local level. There should be clear mechanism so that these agencies will operate in synch, without overlapping and inefficiency.

Fourthly, continuing to support in technology, provide information, strengthen linking between enterprises and the State: Implement support programs; disseminate, apply advanced technology and engineering to SMEs; encourage co-operation and sharing technology between enterprises and large-sized enterprises with foreign investment capital. Form a SMEs support information network; provide information about legal documents, support policies, programs of the Government; upgrade on a comprehensive basis the information gate for enterprises, effectuate connection with information pages, information pages of ministries, sectors, localities. In addition, hold meetings on a regular basis between leadership and local enterprises to exchange information and solve problems, enquiries of SMEs so as to strengthen the linkage between enterprises and the State.

Fifthly, intensify human resource training, refresher training activities for enterprises: Besides supporting in finance for training activities, the role of social associations, organizations should be brought into play in providing advice for SMEs and in improving human resource quality as well. In human resource training for enterprises, emphasis should be placed on training quality, performance; training with focus and priority training for enterprises in some areas oriented towards support from the State.

Sixthly, intensify trade promotion activities: Trade promotion activities plays an important role towards SMEs since this a place where enterprises can learn, exchange experiences and promote their products. The State therefore should hold on a more regular basis trade fairs, exhibitions, talks on special subjects...so that enterprise can have opportunities to join and learn. Such organizations as Vietnam Chamber of Commerce and Industry (VCCI), Vietnam Cooperative Alliance (VCA), Young Entrepreneur Association, Vietnam Association of Small and Medium Enterprises (VINASME) ... are the executors of these trade promotion activities.

\section{Concluding Remarks}

As Vietnam's SMEs has a low starting point, they have to face many difficulties in manufacture and business as well as export activities. However, many enterprises have overcome these difficulties and made considerable contributions to the national economy. In order to confirm their position in the domestic market and over the world, SMEs need to have much more support from State agencies. Vietnam Government always provide enterprises with support in finance, law, investment in technology, manpower development or trade promotion activities... However, the State policies in support of SMEs should be further improved, particularly in the step of implementing, so that all SMEs can have access to such support. The linkage between State agencies and enterprises and economic researchers should be strengthened in order to make development policies proper, close to the actual situation of enterprises and to solve the enquiries which SMEs have to be confronted with. The roadmap for implementing policies in support of SMEs continue but a long way ahead and we can have confidence in the robust growth of Vietnam's SMEs.

\section{References}

Autio, E., Kronlund, M., \& Kovalainen, A. (2007). High-Growth SME Support Initiatives in Nine Countries: Analysis, Categorization, and Recommendations. MTI, Report prepared for the Finnish Ministry of 
Trade and Industry.

Cunningham, P. (2008). Policies in support of high-growth SMEs. Thematic Report. PRO INNO Europe, Inno Policy Trendchart, Manchester Institute of Innovation Research, University of Manchester.

European Commission. (2007). Supporting SME participation in research framework programmes: SMEs and Research: Creating knowledge for growth. European Commission.

Hölzl, W., \& Friesenbichler, K. (2008). Final Sector Report Gazelles. Innovation Watch - Systematic, Europe Innova.

Lilischkis, S. (2011). Policies in support of high-growth innovative SMEs. European CommissionEnterprise and Industry, INNO-Grips Policy Brief No. 2, Version 1.6.

Organisation for Economic Cooperation and Development (OECD). (2010). SMEs, entrepreneurship and innovation. OECD Studies on SMEs and Entrepreneurship.

Roper, S., \& Hart, M. (2013). Supporting sustained growth among SMEs-policy models and guidelines. ERC White Paper No. 7.

Shapero A. (1982). Social Dimensions of Entrepreneurship. In C. Kent, D. Sexton, \& K. Vesper (Eds.), The Encyclopedia of Entrepreneurship (pp. 72-90). Englewood Cliffs: Prentice-Hall.

Tô Hoài, N. (2015). Doanh nghiệp nhỏ và vừa ở Việt Nam hiện nay và nhu cầu hỗ trợ pháp lý. VINASME Hiệp hội doanh nghiệp nhỏ và vìa Việt Nam. Retrieved from http://vinasme.vn/Doanh-nghiep-nho-va-vua-o-Viet-Nam-hien-nay-va-nhu-cau-ho-tro-phap-ly-17-316 9.html

\section{Note}

Note 1. Vietnam Association of Small and Medium Enterprises http://vinasme.vn/default.aspx?kLang=en

\section{Copyrights}

Copyright for this article is retained by the author(s), with first publication rights granted to the journal.

This is an open-access article distributed under the terms and conditions of the Creative Commons Attribution license (http://creativecommons.org/licenses/by/3.0/). 